\title{
Presynaptic muscarinic receptors mediating inhibition of neurogenic contractions in rabbit vas deferens are of the ganglionic $M_{1}$-type
}

\author{
Manfrid Eltze *, Gernot Gmelin ${ }^{1}$, Jürgen Wess ${ }^{2}$, Carsten Strohmann ${ }^{3}$, Reinhold Tacke ${ }^{3}$, \\ Ernst Mutschler ${ }^{2}$ and Günter Lambrecht ${ }^{2}$ \\ Department of Pharmacology, Byk Gulden Pharmaceuticals, D-7750 Konstanz, F.R.G., ' Sandoz Ltd., CH-4002 Basel, Switzerland, \\ 2 Department of Pharmacology, University of D-6000 Frankfurt/M, and ${ }^{3}$ Institute of Inorganic and Analytical Chemistry, \\ Technical University, D.3300 Braunschweig, F.R.G.
}

Received 11 July 1988, revised MS received 2 September 1988, accepted 27 September 1988

The present study was designed to further characterize the presynaptic muscarinic $\mathbf{M}_{1}$-receptor responsible for the inhibition of neurogenic contractions in the isolated rabbit vas deferens. Electrically induced twitch contractions of this preparation were inhibited by the $\mathbf{M}_{1}$-agonist, $\mathrm{McN}-\mathrm{A}-343$, and by some of its analogs: 4-chloro-phenyl derivative $>$ McN-A-343 > trans-olefinic analog > cis-olefinic analog. The same rank order of potency was observed for these agonists to raise the blood pressure of pithed rats by stimulation of $\mathbf{M}_{1}$-receptors in sympathetic ganglia. A highly significant correlation was found between the antimuscarinic potencies of atropine, pirenzepine and a series of 9 antagonists structurally related to the ganglionic $\mathbf{M}_{1 \beta}$-receptor selective compounds, hexocyclium and hexahydro-difenidol, to antagonize the $\mathrm{McN}-\mathrm{A}-343$-induced inhibition of twitch contractions in rabbit vas deferens or the muscarine-induced depolarization in rat isolated superior cervical ganglia. It is suggested that the presynaptic muscarinic receptor that mediates inhibition of neurogenic contractions in rabbit vas deferens is of the ganglionic $\mathbf{M}_{1 \beta}$-type.

Muscarinic receptor subtypes; Vas deferens (rabbit); Pithed rat; Ganglia (rat);

Muscarinic acetylcholine receptor agonists; Muscarinic acetylcholine receptor antagonists; McN-A-343 analogs

\section{Introduction}

It has been shown recently that rabbit vas deferens is endowed with muscarinic $M_{1-}$ and $\mathbf{M}_{2}$-receptors which inversely modulate neurotransmission in this preparation (Eltze, 1988a,b). Activation of the $\mathrm{M}_{1}$-receptors, e.g. by $\mathrm{McN}-\mathrm{A}$ 343 , inhibits neuronally evoked contractions, whereas activation of the $M_{2}$-receptors, e.g. by carbachol, leads to a potentiation of electrically induced twitch contractions. McN-A-343 and

\footnotetext{
* To whom all correspondence should be addressed: Department of Pharmacology, Byk Gulden Pharmaceuticals, D-7750 Konstanz, F.R.G.
}

carbachol have no effect on tension in unstimulated preparations, whereas contractions elicited by exogenously applied $\mathrm{ATP}, \mathrm{KCl}$ and noradrenaline are potentiated by carbachol, but remain unaffected by McN-A-343. Therefore, it has been postulated that the $\mathrm{M}_{1}$-receptor is located presynaptically, and its activation inhibits transmitter (presumably ATP) release, whereas the $\mathbf{M}_{2}$-receptors are located postsynaptically.

The postsynaptic $\mathrm{M}_{2}$-receptor in rabbit vas deferens is of the cardiac $M_{2 \alpha}$-type (Eltze, 1988b), whereas preliminary studies with analogs of $\mathrm{McN}$ A-343 suggest that the presynaptic $M_{1}$-receptor in this organ is pharmacologically similar to the ganglionic $\mathbf{M}_{1}$-subtype (Eltze, 1988a). It has become 
evident recently that $M_{1}$-receptors, similar to $M_{2}$ receptors (Eglen and Whiting, 1986; Lambrecht et al., 1987; Melchiorre et al., 1987), can be further subdivided by functional methods (Lambrecht et al, 1987, 1988a). The most primising tools for this were the muscarinic antagonists hexahydro-difenidol and hexocyclium. The antagonists display considerably higher affinity (159- and 63-fold, respectively) for the $M_{1}$-receptors of rat isolated superior cervical ganglia, which mediate depolarization, than for those present in rat hippocampal pyramidal cells, which mediate an increase in the spike rate (Lambrecht et al., 1988b). Based on these antagonist potencies and on the results obtained with the agonist, McN-A-343 (see Discussion), it was proposed that $\mathrm{M}_{1}$-receptors should be subclassified into two subtypes (Lambrecht et al., 1987, 1988b; Mutschler et al., 1987, 1988): $\mathbf{M}_{1 \alpha}$ (hippocampal type) and $M_{1 \beta}$ (ganglionic type).

To further characterize the presynaptic $M_{1}$-receptors in rabbit vas deferens, the affinities of hexocyclium, hexahydro-difenidol and several analogs (fig. 2) for the $M_{1}$-receptors in this organ were compared with those for the receptors in rat isolated superior cervical ganglia. We also compared the agonistic potencies of McN-A-343 and some analogs (fig. 1) to inhibit neurogenic contractions in rabbit vas deferens with their potencies to raise blood pressure in pithed rats.

\section{Materials and methods}

\subsection{Isolated rabbit vas deferens}

Male New Zealand white rabbits $(2.5-3.0 \mathrm{~kg})$ were killed by exsanguination after the animals had been anaesthetized with pentobarbitone sodium $(60 \mathrm{mg} / \mathrm{kg}$ i.v.) and the vasa deferentia were removed. The organs were carefully dissected free of surrounding tissue and divided into four segments, two prostatic portions $(1 \mathrm{~cm})$ and two epididymal portions (approximately $1.5 \mathrm{~cm}$ ). Each segment was folded in two and fixed vertically in

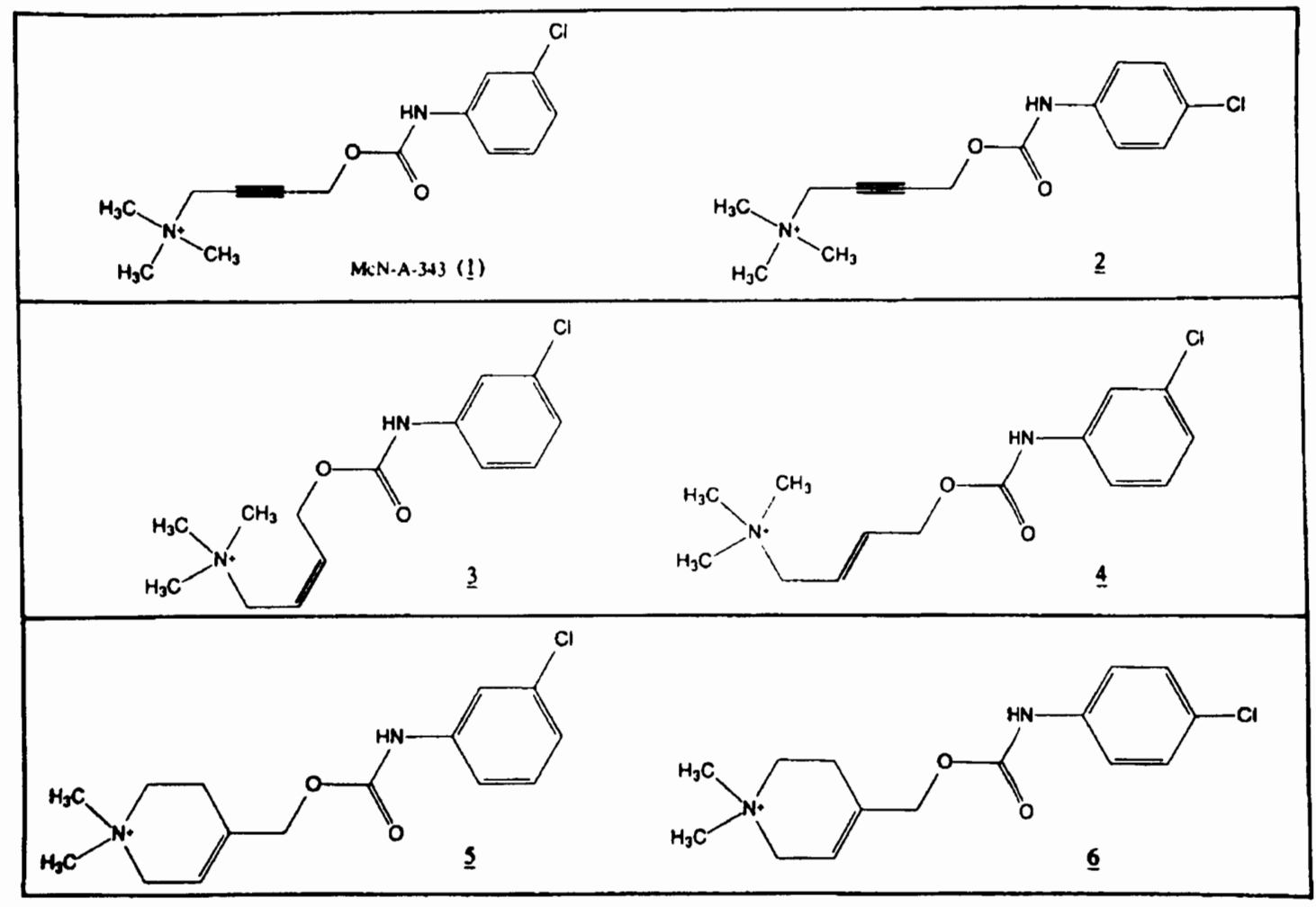

Fig. 1. Chemical structure of McN-A-343 (1) and analogs 2-6. 


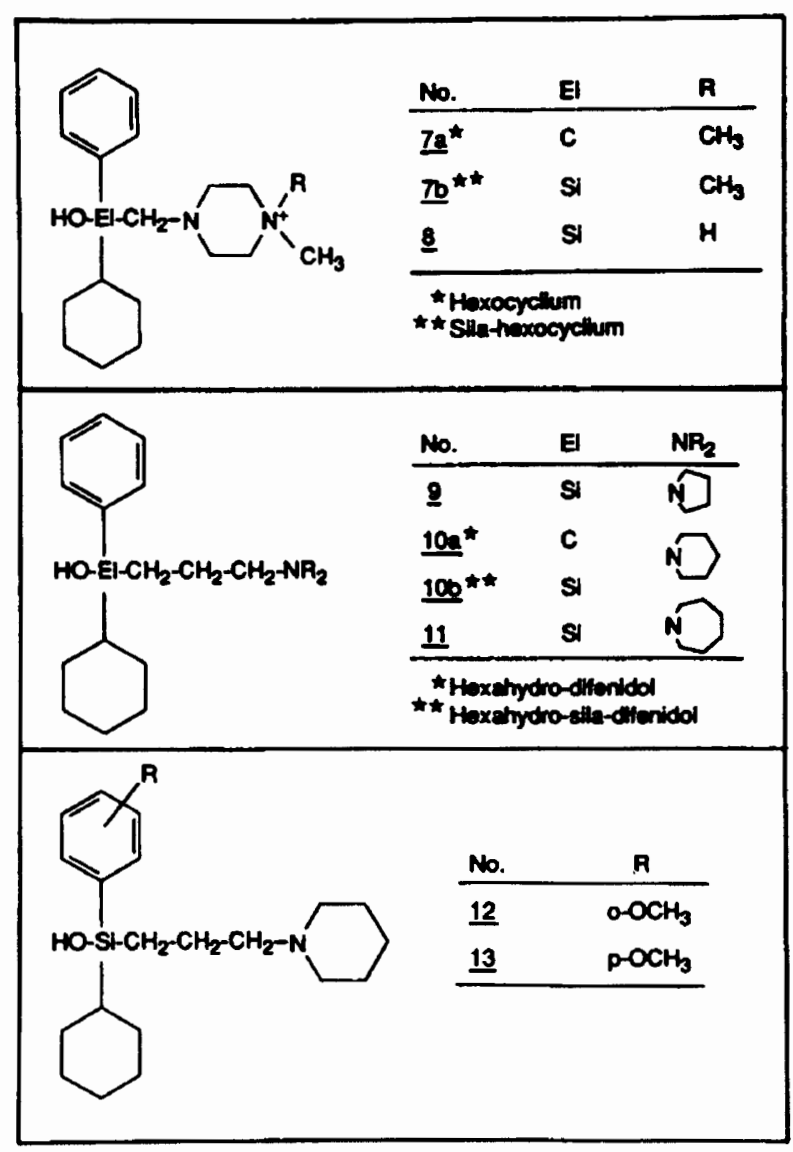

Fig. 2. Chemical structure of antagonists of the hexocyclium (7a) and hexahydro-difenidol (10a) type.

a $10 \mathrm{ml}$ water-jacketed organ bath by means of a hook-shaped platinum electrode and a cotton thread connected to a force-displacement transducer. A second platinum ring electrode was placed at the top of the bathing fluid which consisted of (mM): $\mathrm{NaCl} 118.0, \mathrm{KCl} 4.7, \mathrm{CaCl}_{2} 2.5, \mathrm{MgSO}_{4}$ $0.6, \mathrm{KH}_{2} \mathrm{PO}_{4} 1.2, \mathrm{NaHCO}_{3} 25.0$ and glucose 11.1; $10^{-6} \mathrm{M}$ yohimbine was included to block $\alpha_{2}$ adrenoceptors.

The bath solution was maintained at $31^{\circ} \mathrm{C}$ and was continuously bubbled with $95 \% \mathrm{O}_{2}-5 \% \mathrm{CO}_{2}$. The preparations were preloaded with $0.75 \mathrm{~g}$ and were left to equilibrate for $30 \mathrm{~min}$ before starting the continuous field stimulation $(0.5 \mathrm{~ms}, 30 \mathrm{~V}$, $0.05 \mathrm{~Hz}$ ). The contractions of eight preparations, run in parallel, were measured isometrically (K-30, Hugo Sachs Elektronik) and recorded on multichannel recorders (Kipp and Zonen, BD 9).

\subsubsection{Agonist potencies}

Following the stabilization of the contractile response to electrical field stimulation, cumulative concentration-response curves to muscarinic receptor agonists were made. The concentration of agonist was increased as soon as a stable response to the previous concentration was achieved. The apparent potency of an agonist was expressed by its $-\log \mathrm{EC}_{50}$ value, i.e. the $-\log$ of the molar concentration that induced a response that was $50 \%$ of the individual maximal effect.

\subsubsection{Antagonist affinities}

Eight preparations were used to determine two or three reproducible concentration-response curves for McN-A-343 (1) $\left(10^{-7}-2 \times 10^{-6} \mathrm{M}\right)$. Subsequent curves were then obtained at $45 \mathrm{~min}$ intervals, the antagonist being added $15 \mathrm{~min}$ before the agonist. Schild plots were constructed from the dose-ratios of the agonist obtained for three to five different antagonist concentrations to estimate the $\mathrm{pA}_{2}$ value with confidence limits and the slope of the regression line (Arunlakshana and Schild, 1959). The experimental data were fitted by a conventional least-squares method (Waud and Parker, 1971).

\subsection{Isolated superior cervical ganglion of the rat}

Experiments on ganglia were performed as described by Brown et al. (1980). Superior cervical ganglia were excised from male Sprague-Dawley rats $(200-300 \mathrm{~g})$ that had been anaesthetized with urethane $(1.2 \mathrm{~g} / \mathrm{kg}$ i.p.). Each ganglion was desheathed, suspended vertically in a separate heated chamber $\left(36^{\circ} \mathrm{C}\right)$ and superfused with oxygenated $\left(\begin{array}{lll}95 \% & \mathrm{O}_{2}-5 \% & \mathrm{CO}_{2}\end{array}\right)$ Krebs solution $(1 \mathrm{ml} / \mathrm{min})$ which consisted of $(\mathrm{mM}): \mathrm{NaCl} 124.0, \mathrm{KCl} 3.0$, $\mathrm{NaHCO}_{3} 26.0, \mathrm{NaH}_{2} \mathrm{PO}_{4} 1.25, \mathrm{CaCl}_{2} 2.0, \mathrm{MgCl}_{2}$ 2.0 and glucose 10.0. The muscarine-induced depolarization $\left(\mathrm{pD}_{2}=7.4\right)$ was recorded differentially, via two calomel electrodes, between the ganglion and its postganglionic trunk. The DC potentials were amplified by microvoltmeters (KEITHLEY 177) and were monitored on a chart recorder. To obtain dose-response curves, single doses of muscarine were applied at 20-45 min intervals, followed by a washout phase until the baseline was reached. 
To determine the antagonistic effects of the drugs, dose-response curves for muscarine were obtained before and after the addition of an antagonist which was allowed to equilibrate for 30 min. Two or three different concentrations of each antagonist were tested and the dose ratios for the antagonist-induced parallel shifts of the muscarine dose-response curves were estimated. The $\mathrm{pA}_{2}$ values were calculated from individual dose ratios according to Arunlakshana and Schild (1959).

\subsection{Pithed rat preparation}

Male Wistar rats (200-350 g) were anaesthetized with pentobarbitone sodium $(60 \mathrm{mg} / \mathrm{kg}$ i.p.). The left jugular vein was cannulated for the administration of drugs. Arterial blood pressure was measured from the cannulated right common carotid artery by means of a Statham pressure transducer connected to a Hellige amplifier and a Rikadenki recorder. After cannulation of the trachea, the rats were pithed by introducing a steel rod into the spinal canal. The rats were artificially respirated with room air by means of a BraunMelsungen pump ( $1 \mathrm{ml} / 100 \mathrm{~g}$ body weight; 60 strokes/min). Heparin (150 I.U./kg i.v.) was given to prevent coagulation of the blood. Body temperature was kept at $37 \pm 1{ }^{\circ} \mathrm{C}$ throughout the experiment by means of an overhead heating lamp.

\subsubsection{Experimental protocol}

All agonists were dissolved in saline $(0.9 \% \mathrm{w} / \mathrm{v})$ and increasing doses were injected i.v. in a volume of $0.1 \mathrm{ml} / 100 \mathrm{~g}$ at $10-15 \mathrm{~min}$ intervals until an increase in mean arterial pressure of about $80-100$ $\mathrm{mm} \mathrm{Hg}$ was obtained. As a measure of agonist potencies, the doses that caused a blood pressure increase of $70 \mathrm{~mm} \mathrm{Hg}$ ( $\mathrm{ED}_{70}$ values) were determined graphically from the dose-response curves.

\subsection{Drugs}

The following drugs were used: heparin sodium (Promonta); pentobarbitone sodium (Abott); pirenzepine dihydrochloride (Boehringer Ingelheim); McN-A-343 (1), 4-[m-chlorophenylcarbamoyloxy]2-butynyltrimethylammonium chloride
(RBI, Wayland, USA); Atropine sulfate, d,l-muscarine chloride, yohimbine hydrochloride (Sigma). McN-A-343 analogs 3 and 4 were kindly donated by Dr. W.L. Nelson, University of Washington, USA. Compounds 2 and 5-13 were synthesized in our laboratories (Lambrecht et al., 1986: 2, 5, 6; Zaugg et al., 1958: 7a; Tacke et al., 1988: 7b, 8; Tacke et al., 1985: 10a. 10b; compounds 9 and 11-13 were synthesized by a method similar to that used to prepare the parent compound $10 \mathrm{~b}$, unpublished results).

\section{Results}

\subsection{Response of the rabbit vas deferens to muscarinic agonists}

Electrical field stimulation of the isolated rabbit vas deferens elicited individual phasic contractions of the 'rapid twitch' type, which were reproducible for more than $6 \mathrm{~h}$. McN-A-343 (1) and the analogs 2-6 caused a dose-dependent inhibition of these twitch responses (fig. 3). However, only McN-A-343 (1) and its 4-chloro-phenyl derivative 2 completely inhibited the twitch contractions at high concentrations (fig. 3, table 1). Whereas 2 proved to be 2.3 times more potent than McN-A343 itself, the olefinic derivatives 3 and 4 showed a relative potency (compared to $\mathrm{McN}-\mathrm{A}-343$ ) of 0.13 and 0.52 , respectively (fig. 3 , table 1 ). The maximal inhibition of twitch responses achieved by the cis-isomer 3 (36\% inhibition) was considerably lower than that obtained with the trans-analog 4 (84\% inhibition). The cyclic isoarecolinol derivatives 5 and 6 proved to be weak partial agonists, whereby the 4-chloro derivative 6 showed a somewhat greater efficacy. The twitch-inhibiting effect of McN-A-343 (1) and analogs 2-6 was readily reversible on washing. All agonists tested had no effect on the base-line tension of the stimulated or quiescent organs at concentrations that markedly inhibited the twitch contractions.

\subsection{Effect of muscarinic antagonists in rabbit vas deferens}

Atropine, pirenzepine and compounds 7-13 inhibited the McN-A-343-induced decrease in con- 


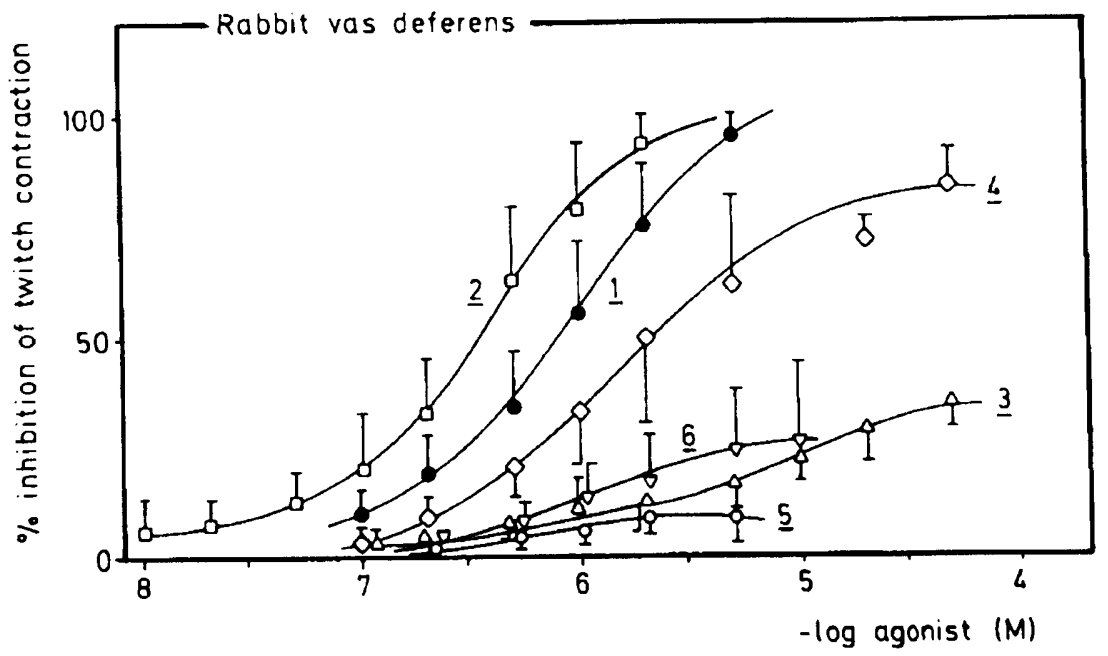

Fig. 3. Concentration-response curves for the inhibitory effects of McN-A-343 (1) and analogs 2-6 on contractions induced by field stimulation in the rabbit vas deferens (means \pm S.D., $n=12-22$ ).

traction amplitude in the field-stimulated rabbit vas deferens. All antagonists shifted the McN-A343 dose-response curves to the right in a parallel fashion and did not depress the maximal inhibition caused by the agonist (data not shown), thus indicating competitive antagonism. However, in some cases (atropine, 7a, 7b, 10a, 11, 12), the slopes of the Schild plots were found to be significantly different from unity (table 2). As shown in table 2 , the affinities of atropine, pirenzepine and

\section{TABLE 1}

Potency of McN-A-343 (1) and analogs 2-6 to inhibit twitch contractions in the field-stimulated rabbit vas deferens.

\begin{tabular}{lllll}
\hline Agonist & $\begin{array}{l}-\log \mathrm{EC}_{50}{ }^{a} \\
\text { Mean } \\
\text { (95\% conf. lim.) }\end{array}$ & $\begin{array}{l}\text { Maximal }_{\text {effect }^{b}} \\
(\text { mean } \pm \text { S.D.) }\end{array}$ & Potency $^{c} \mathrm{n}$ \\
\hline McN-A- & & & & \\
$343(1)$ & $6.10(5.53 ; 6.66)$ & 1.00 & 1.00 & 18 \\
2 & $6.46(5.83 ; 7.10)$ & 1.00 & 2.3 & 22 \\
3 & $5.22(4.57 ; 5.81)$ & $0.36 \pm 0.07$ & 0.13 & 12 \\
4 & $5.82(5.33 ; 6.31)$ & $0.84 \pm 0.08$ & 0.52 & 14 \\
5 & - & $0.09 \pm 0.06$ & - & 19 \\
6 & $\approx 6.0(-;-)$ & $0.26 \pm 0.19$ & 0.79 & 17 \\
\hline
\end{tabular}

Negative log molar concentration producing $50 \%$ of the maximum response. ${ }^{b}$ Maximal inhibition obtained in relation to the maximal effect of McN-A-343 (=1.00). ${ }^{c}$ Relative potency was calculated from the antilog of differences between the $-\log \mathrm{EC}_{30}$ values for the respective agonist and for $\mathrm{McN}$ A-343 which has been arbitrarily assigned a value of 1.00 . compounds $7-13$ for muscarinic $M_{1}$-receptors in rabbit vas deferens differed by more than two orders of magnitude.

\subsection{Effect of muscarinic antagonists in rat superior cervical ganglia}

The muscarine-induced depolarization of the ganglia was antagonized by atropine, pirenzepine

\section{TABLE 2}

The affinities of the antagonists for muscarinic $M_{1}$-receptors in rabbit vas deferens, related to their inhibition of the McN-A343-induced decrease of contraction to field stimulation. The $\mathrm{pA}_{2}$ values (mean with $95 \%$ confidence limits) and slopes of regression lines (mean \pm S.D.) were calculated from Schild plots.

\begin{tabular}{|c|c|c|c|}
\hline & $\mathrm{pA}_{2}$ & Slope & $\mathrm{n}$ \\
\hline Atropine & $9.16(8.22 ; 10.21)^{a}$ & $1.69 \pm 0.20^{b}$ & 12 \\
\hline Pirenzepine & $7.64(7.13 ; 8.19)^{a}$ & $1.22 \pm 0.09$ & 16 \\
\hline $7 a^{c}$ & $8.99(8.35 ; 9.63)$ & $1.44 \pm 0.08^{b}$ & 19 \\
\hline $7 b^{d}$ & $8.95(8.37 ; 9.53)$ & $1.34 \pm 0.23^{b}$ & 20 \\
\hline 8 & $7.60(7.06 ; 8.14)$ & $1.20 \pm 0.11$ & 10 \\
\hline 9 & $7.76(7.04 ; 8.51)$ & $1.07 \pm 0.04$ & 12 \\
\hline $10 \mathrm{a}^{e}$ & $7.75(7.21 ; 8.28)$ & $1.22 \pm 0.06^{b}$ & 12 \\
\hline $10 b^{t}$ & $7.88(7.42 ; 8.38)$ & $1.09 \pm 0.03$ & 19 \\
\hline 11 & $7.02(6.37 ; 7.67)$ & $1.23 \pm 0.07^{b}$ & 12 \\
\hline 12 & $6.77(6.15 ; 7.39)$ & $1.21 \pm 0.06^{b}$ & 10 \\
\hline 13 & $6.72(6.20 ; 7.25)$ & $1.06 \pm 0.04$ & 11 \\
\hline
\end{tabular}

a Data taken from Eltze (1988b). ${ }^{b}$ Slope significantly different from unity $(P<0.05)$. ${ }^{c}$ Hexocyclium. ${ }^{d}$ Sila-hexocyclium.

'Hexahydro-difenidol. ' Hexahydro-sila-difenidol. 


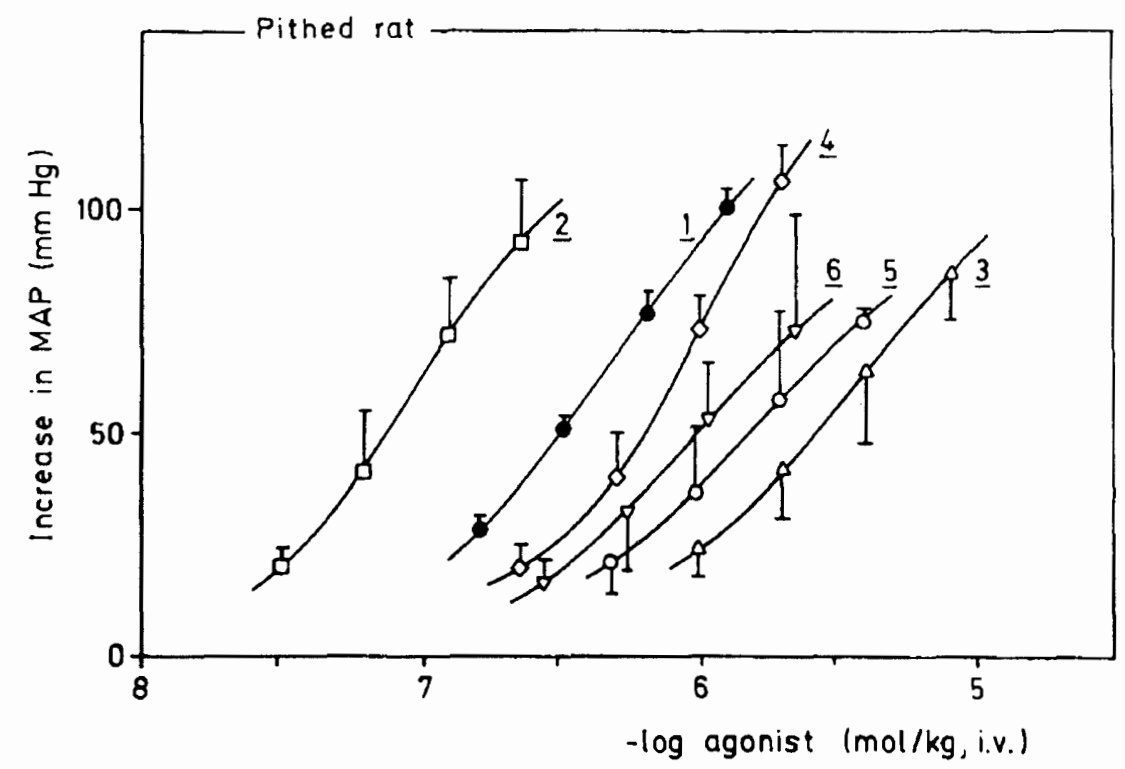

Fig. 4. Dose-response curves for the increase in mean arterial pressure (MAP) caused by McN-A-343 (1) and analogs 2-6 in the pithed rat (means \pm S.D., $n=2-7$ ).

and compounds 7-13. All antagonists produced a parallel shift of the muscarine dose-response curve, and none of these drugs consistently reduced the maximum response to muscarine, obviously indicating competitive antagonism. As shown in table 3 , compound 7-13 showed quite wide variations in their affinity for ganglionic muscarinic $M_{1}$-recep-

\section{TABLE 3}

The affinities of the antagonists for muscarinic $\mathbf{M}_{\mathbf{1}}$-receptors in rat superior cervical ganglia, related to their inhibition of the muscarine-induced depolarization. The mean $\mathrm{pA}_{2}$ values and their $95 \%$ confidence limits are given. $n$ indicates the number of independent experiments.

\begin{tabular}{llr}
\hline & $\mathrm{pA}_{2}$ & $\mathrm{n}$ \\
\hline Atropine & $9.1(9.0 ; 9.2)$ & 10 \\
Pirenzepine & $8.3(8.2 ; 8.4)^{\mathrm{a}}$ & 12 \\
$\mathbf{7 a}^{\mathrm{b}}$ & $8.8(8.5 ; 9.1)$ & 6 \\
$\mathbf{7 b}^{\mathrm{c}}$ & $9.6(9.2 ; 10.0)$ & 12 \\
$\mathbf{8}$ & $7.6(7.3 ; 7.9)$ & 15 \\
9 & $7.7(7.5 ; 7.9)$ & 15 \\
$\mathbf{1 0 a ^ { d }}$ & $7.9(7.6 ; 8.2)$ & 6 \\
$10 \mathrm{~b}^{\mathrm{e}}$ & $7.3(7.2 ; 7.4)$ & 12 \\
11 & $6.9(6.6 ; 7.2)$ & 8 \\
12 & $6.7(6.4 ; 7.0)$ & 9 \\
13 & $6.4(6.2 ; 6.6)$ & 10 \\
\hline
\end{tabular}

$\bar{a}$ Data taken from Lambrecht et al. (1988a). ${ }^{b}$ Hexocyclium. c Sila-hexocyclium. d Hexahydro-difenidol. ${ }^{\mathrm{e}}$ Hexahydro-siladifenidol. tors. Their $\mathrm{pA}_{2}$ values differed by up to three orders of magnitude.

\subsection{Pressor effects of muscarinic agonists in the pithed rat}

The initial mean arterial pressure of the pithed rats prior to drug treatment was $50 \pm 9 \mathrm{~mm} \mathrm{Hg}$ (mean \pm S.D., $n=22$ ). McN-A-343 (1) and the analogs 2-6 caused a dose-dependent rise in the mean arterial pressure of the pithed rat (fig. 4). All pressor responses were highly sensitive to blockade by low doses $(100-300 \mu \mathrm{g} / \mathrm{kg}$ i.v.) of the

\section{TABLE 4}

The pressor activity of McN-A-343 (1) and analogs 2-6 in pithed rats. The $-\log E D_{70}$ values refer to the doses of the agonists that cause an increase of $70 \mathrm{~mm} \mathrm{Hg}$ in the mean arterial blood pressure. The values are presented as the means with $95 \%$ confidence limits $(n=2-7)$.

\begin{tabular}{ll}
\hline Agonist & $-\log \mathrm{ED}_{70}(\mathrm{~mol} / \mathrm{kg}$ i.v. $)$ \\
\hline McN-A-343(1) & $6.27(6.23 ; 6.31)$ \\
$\mathbf{2}$ & $6.93(6.73 ; 7.13)$ \\
$\mathbf{3}$ & $5.35(5.18 ; 5.52)$ \\
4 & $6.04(5.98 ; 6.10)$ \\
$\mathbf{5}$ & $5.60(5.31 ; 5.89)$ \\
6 & $5.89(5.69 ; 6.09)$ \\
\hline
\end{tabular}


selective $\mathrm{M}_{1}$-receptor antagonist, pirenzepine (data not shown). As a measure of the agonist potencies of these compounds, $-\log \mathrm{ED}_{70}$ values $\left(\mathrm{ED}_{70}=\right.$ agonist dose corresponding to an increase in mean arterial pressure by $70 \mathrm{~mm} \mathrm{Hg}$ ) are listed in table 4. The 4-chlorophenyl derivative $2\left(\mathrm{ED}_{70}=0.12\right.$ $\mu \mathrm{mol} / \mathrm{kg}$ i.v.) was ca. 4.5 times more potent than $\mathrm{McN}-\mathrm{A}-343\left(\mathrm{ED}_{70}=0.53 \mu \mathrm{mol} / \mathrm{kg}\right.$ i.v.). Whereas the trans-olefinic analog $3\left(\mathrm{ED}_{70}=0.91 \mu \mathrm{mol} / \mathrm{kg}\right.$ i.v.) showed a relative potency of about 0.5 (compared to McN-A-343), the cis-olefinic isomer 4 $\left(\mathrm{ED}_{70}=4.63 \mu \mathrm{mol} / \mathrm{kg}\right.$ i.v. $)$ was about one order of magnitude less potent than the parent compound. The two cyclic derivatives 5 and $6\left(\mathrm{ED}_{70}\right.$ $=2.77$ and $1.36 \mu \mathrm{mol} / \mathrm{kg}$ i.v., respectively) were less active than McN-A-343 by a factor of about 5 and 3.5 , respectively.

\subsection{Comparison of agonist potencies in rabbit vas deferens and pithed rats}

A significant correlation was found between the $-\log \mathrm{EC}_{50}$ values of the agonists $1-4$ and 6 for the inhibition of twitch contractions in the rabbit vas deferens (table 1) and the $-\log \mathrm{ED}_{70}$ values for the rise in mean arterial blood pressure in pithed rats (table 4). This correlation $(r=0.95$, slope $=$ $0.75, \mathrm{P}<0.01)$ is shown in fig. 5.

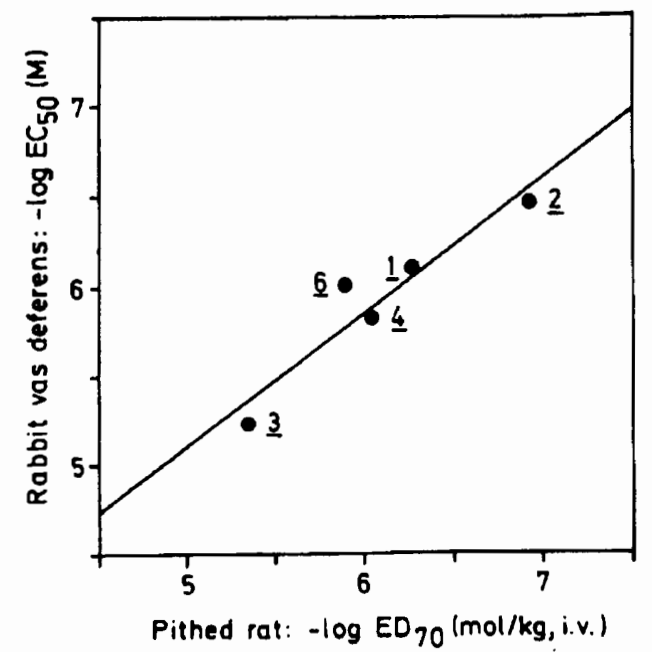

Fig. 5. Comparison between the potencies of McN-A-343 (1), analogs 2-4 and 6 to inhibit twitch contractions in rabbit vas deferens $\left(-\log \mathrm{EC}_{50}, \mathrm{M}\right)$ and their ability to increase mean arterial blood pressure by $70 \mathrm{~mm} \mathrm{Hg}\left(-\log \mathrm{ED}_{70}, \mathrm{~mol} / \mathrm{kg}\right.$, i.v.) in pithed rats.

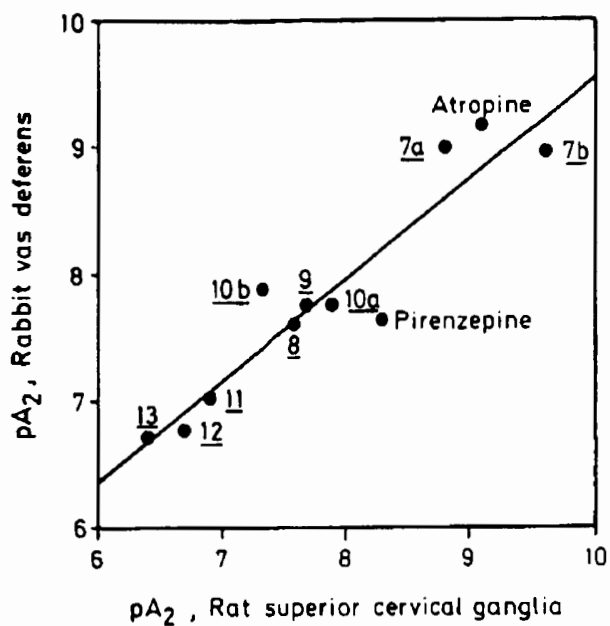

Fig. 6. Comparison between the affinities ( $\mathrm{pA}_{2}$ values) of different antimuscarinic drugs listed in table 2 and 3 for muscarinic $\mathbf{M}_{1}$-receptors in rabbit vas deferens and rat superior cervical ganglia.

\subsection{Comparison of antagonist affinities in rabbit vas deferens and rat superior cervical ganglia}

A significant correlation $(r=0.94$, slope $=0.80$, $\mathrm{P}<0.001$; fig. 6) was found between the $\mathrm{pA}_{2}$ values for atropine, pirenzepine and compounds 7-13 obtained in rabbit vas deferens (table 2) and those obtained in rat ganglia (table 3 ).

\section{Discussion}

It has been shown recently (Eltze, 1988a,b) that the McN-A-343-induced inhibition of neurogenic twitch contractions of the isolated rabbit vas deferens is mediated by stimulation of presynaptic muscarinic heteroreceptors of the $\mathbf{M}_{1}$-type. The transmitter released by field stimulation appears to be ATP (Eltze, 1988b; Sneddon et al., 1984).

Recent evidence suggests that $\mathbf{M}_{1}$-receptors do not form a homogeneous population, but may be further subclassified into at least two subtypes: $\mathrm{M}_{1 \alpha^{-}}$(hippocampal type) and $\mathrm{M}_{1 \beta^{-}}$(ganglionic type) receptors (Lambrecht et al., 1987; 1988b; Mutschler et al., 1987; 1988). In the present study, we have investigated the actions of a series of agonists and antagonists at $\mathbf{M}_{1}$-receptors in the isolated rabbit vas deferens and compared these actions with their effects at $M_{1}$-receptors in rat 
sympathetic ganglia in vitro and in vivo. The principal conclusion we draw from these experiments is that the presynaptic $\mathbf{M}_{1}$-receptors present in the rabbit vas deferens are pharmacologically very similar to those that mediate depolarization in rat sympathetic ganglia.

McN-A-343 (1) and analogs 2-6 produced a concentration-dependent inhibition of twitch contractions in the electrically stimulated rabbit vas deferens (fig. 3). However, classical muscarinic agonists, such as carbachol or oxotremorine, caused a potentiation of twitch contractions via activation of postsynaptic $\mathrm{M}_{2 \alpha^{-}}\left(\mathrm{M}_{2}\right.$ cardiac type) receptors (Eltze, 1988a,b). As the inhibitory effects of McN-A-343 in the rabbit vas deferens have been shown to be mediated by the activation of presynaptic $M_{1}$-receptors (Eltze, 1988a,b), these findings further support the view that $\mathrm{McN}-\mathrm{A}-343$ and several of its analogs may be regarded as selective $M_{1}$-receptor stimulants (Hammer and Giachetti, 1982; Lambrecht et al., 1986; Micheletti et al., 1988).

In the pithed rat, McN-A-343 and the analogs 2-6 produced dose-dependent pressor effects (fig. 4) which are known to be mediated by stimulation of $\mathbf{M}_{1}$-receptors in sympathetic ganglia (Hammer and Giachetti, 1982; Wess et al., 1984; Lambrecht et al., 1986). Interestingly, the agonist potencies of compounds 1-6 on the vas deferens and in pithed rats were strikingly similar, as measured by their $\mathrm{EC}_{50}$ and $\mathrm{ED}_{70}$ values (table 1 and 4), both individually and in rank order. A highly significant correlation was found between these values (fig. 5). This implies that the structural and stereochemical demands on compounds 1-6 made by the $M_{1}$-receptors of the vas deferens and sympathetic ganglia are similar. 4-Chloro substitution of both $\mathrm{McN}-\mathrm{A}-343$ (1) and the quaternary isoarecolinol derivative 5 led to an increase in potency (compounds 2 and 6). Thus, the 4-chloro $\mathrm{McN}-\mathrm{A}-343$ analog 2 represents the most potent $M_{1}$-agonist known so far. The trans-olefinic analog 4 was found to be nearly as potent as McN-A-343 (1) in rabbit vas deferens and pithed rats, whereas the cis-isomer 3 was about one order of magnitude less potent in both preparations. This observation might be explained by the fact that certain low energy conformations of $\mathrm{McN}-\mathrm{A}-343$ can be closely approximated by the trans-stereoisomer 4 . in which the quaternary nitrogen atom and the carbamate ether oxygen are about $0.57 \mathrm{~nm}$ apart in a nearly fully extended conformation (fig. 1). In contrast, the cis-isomer 3 cannot be fit to such a pattern (Nelson et al., 1973).

Atropine, pirenzepine and compounds 7-13 caused a concentration-dependent blockade of muscarinic $\mathbf{M}_{1}$-receptors in the rabbit vas deferens and rat superior cervical ganglia. The concentration-response curves for the agonists, McN-A-343 and muscarine, were shifted to the right in a parallel fashion and the maximum effects of the agonists were not depressed. However, in some cases the slopes of the Schild plots obtained from the rabbit vas deferens experiments were found to be significantly greater than unity. Thus, the respective $\mathrm{pA}_{2}$ values might be underestimated slightly. An insufficient equilibration time might account for this phenomenon (Kenakin, 1982).

Compounds 7-13 showed quite wide variations in their affinities for the $M_{1}$-receptors in both vas deferens and ganglia (table 2 and 3), their $\mathrm{pA}_{2}$ values differing by nearly three orders of magnitude. The $\mathrm{pA}_{2}$ values determined for pirenzepine ( 7.64 and 8.3 , respectively) were close to the $M_{1}$ affinities found previously in binding studies with calf sympathetic and human stellate ganglia ( $-\log$ $\mathrm{K}_{\mathrm{i}}=8.0$ and 7.85 , respectively) (Giraldo et al., 1985; Watson et al., 1984). Moreover, the sensitivities of the $M_{1}$-receptors in the rabbit vas deferens and in rat superior cervical ganglia to atropine and compounds 7-13 were also strikingly similar, as shown by their $\mathrm{pA}_{2}$ values (table 2 and 3; fig. 6), again both individually and in rank order. This means that the structural demands on the antagonists made by the $M_{1}$ - receptors are very similar in both tissues.

Taking into account that most of the antagonists used in this study $(7 \mathrm{a}, 7 \mathrm{~b}, 8,9,10 \mathrm{a}, 10 \mathrm{~b}$ and 12) possess a higher affinity for ganglionic $\mathbf{M}_{1 \beta^{-}}$(this study) than for hippocampal $\mathrm{M}_{1 \alpha}$-receptors (Lambrecht et al., 1987, 1988b) by factors of $10-160$, these data indicate that the muscarinic inhibition of neurogenic contractions in rabbit vas deferens is mediated by presynaptic $\mathbf{M}_{1 \beta}$-receptors $\left(M_{1}\right.$ ganglionic type). This view is further supported by the observation that the $\mathrm{M}_{1}$-agonist, 
McN-A-343 (1), is highly potent at ganglionic $M_{1 \beta^{-}}$-receptors in vitro (Palacios et al., 1986) and at $\mathbf{M}_{1}$-receptors in the rabbit vas deferens but has only very weak, if any, stimulating properties at hippocampal $\mathbf{M}_{1 \alpha}$-receptors (Gmelin, 1985).

In conclusion, we have provided pharmacological evidence that the muscarinic presynaptic heteroreceptors in rabbit vas deferens that mediate inhibition of neurogenic contractions are similar to the $\mathrm{M}_{1 \beta^{-}}$-receptors in rat sympathetic ganglia in terms of agonist potencies and antagonist affinities. Presynaptic $\mathrm{M}_{1}$-receptors have also been found in chicken heart (Jeck et al., 1988), different guinea-pig and rat brain areas (Belleroche and Gardiner, 1985; Marchi et al., 1986; Williams and Constanti, 1988) as well as in guinea-pig and rat small intestine (Micheletti et al., 1988; Schwörer and Kilbinger, 1988). However, it remains to be elucidated whether all these presynaptic muscarinic receptors are pharmacologically identical or whether they belong to different $\mathbf{M}_{1}$-receptor subclasses.

\section{Acknowledgements}

R.T. thanks the Deutsche Forschungsgemeinschaft and the Fonds der Chemischen Industrie for financial support as well as the Bayer AG, Leverkusen and Wuppertal-Elberfeld, for support with chemicals. G.L. and E.M. thank the Fonds der Chemischen Industrie for financial support. The authors wish to thank Mrs. G. Langenstein for carefully typing the manuscript.

\section{References}

Arunlakshana, O. and H.O. Schild, 1959, Some quantitative uses of drug antagonists, Br. J. Pharmacol. 14, 48.

Belleroche, J. and I.M. Gardiner, 1985, Muscarinic receptors discriminated by pirenzepine are involved in the regulation of neurotransmitter release in rat nucleus accumbens, $\mathrm{Br}$. J. Pharmacol. 86, 505.

Brown, D.A., S. Fatherazi, J. Garthwaite and R.D. White, 1980 , Muscarinic receptors in rat sympathetic ganglia, Br. J. Pharmacol. 70, 577.

Eglen, R.M. and R.L. Whiting, 1986, Muscarinic receptor subtypes: A critique of the current classification and a proposal for a working nomenclature, J. Auton. Pharmacol. 5, 323.
Eltze, M., 1988a, Rabbit isolated vas deferens: a novel, functional method for measuring M1-/M2-receptor drug selectivity, Naunyn-Schmiedeb. Arch. Pharmacol. 337 (Suppl.), R91.

Eltze, M., 1988b, Muscarinic M1- and M2-receptors mediating opposite effects on neuromuscular transmission in rabbit vas deferens, European J. Pharmacol. 151, 205.

Giraldo, E., E. Monferini and R. Hammer, 1985, Selective labelling of M1-receptors in autonomic ganglia with ${ }^{3} \mathrm{H}$ pirenzepine, Arzneim. Forsch./Drug Res. 35, 325.

Gmelin, G., 1985, Effects of muscarinic agonists and antagonists in the hippocampal slice preparation, Neurosci. Lett. 22 (Suppl.), 540.

Hammer, R. and A. Giachetti, 1982, Muscarinic receptor subtypes: M1 and M2, biochemical and functional characterization, Life Sci. 31, 2991.

Jeck, D., R. Lindmar, K. Löffelholz and M. Wanke, 1988, Subtypes of muscarinic receptor on cholinergic nerves and atrial cells of chicken and guinea-pig hearts, Br. J. Pharmacol. 93, 357.

Kenakin, T.P., 1982, The Schild regression in the process of receptor classification, Can. J. Physiol. Pharmacol. 60, 249.

Lambrecht, G., U. Moser, E. Mutschler, G. Walther and J. Wess, 1986, Muscarinic ganglionic stimulants: Conformationally restrained analogues related to $[4-[[\mathrm{N}$-(3-chlorophenyl)carbamoyl]oxy]-2-butynyl]trimethylammonium chloride, J. Med. Chem. 29, 1309.

Lambrecht, G., E. Mutschler, U. Moser, J. Riotte, M. Wagner, J. Wess, G. Gmelin, R. Tacke and H. Zilch, 1987, Heterogeneity in muscarinic receptors: Evidence from pharmacological and electrophysiological studies with selective antagonists, in: International Symposium on Muscarinic Cholinergic Mechanisms, eds. S. Cohen and M. Sokolovsky (Freund Publishing House Ltd., London) p. 245.

Lambrecht, G., G. Gmelin, K. Rafeiner, C. Strohmann, R. Tacke and E. Mutschler, 1988a, o-Methoxy-sila-hexocyclium: A new quaternary $\mathbf{M}_{1}$-selective muscarinic antagonist, European J. Pharmacol. 151, 155.

Lambrecht, G., U. Moser, M. Wagner, J. Wess, G. Gmelin, K. Rafeiner, C. Strohmann, R. Tacke and E. Mutschler, 1988b, Pharmacological and electrophysiological evidence for muscarinic $M_{1}$ and $M_{2}$ receptor heterogeneity, Trends Pharmacol. Sci. 9 (suppl.), 82.

Marchi, M., P. Paudice, M. Bella and M. Raiteri, 1986, Dicyclomine- and pirenzepine-sensitive muscarinic receptors mediate inhibition of $\left[{ }^{3} \mathrm{H}\right]$ serotonin release in different rat brain areas, European J. Pharmacol. 129, 353.

Melchiorre, C., P. Angeli, G. Lambrecht, E. Mutschler, M.T. Picchio and J. Wess, 1987, Antimuscarinic action of methoctramine, a new cardioselective $\mathrm{M}-2$ muscarinic receptor antagonist, alone and in combination with atropine and gallamine, European J. Pharmacol. 144, 117.

Micheletti, R., A. Schiavone and A. Giachetti, 1988, Muscarinic M1 receptors stimulate a nonadrenergic noncholinergic inhibitory pathway in the isolated rat duodenum, J. Pharmacol. Exp. Ther. 244, 680. 
Mutschler, E., G. Gmelin. U. Moser, J. Wess and G. Lambrecht, 1987. Structure-activity relationships of drugs acting selectively at different muscarinic receptors, in: Pharmacology, International Congress Series No. 750, eds. M.J. Rand and C. Raper (Elsevier Science Publishers B.V., Amsterdam) p. 67.

Mutschler, E., U. Moser, J. Wess and G. Lambrecht, 1988, New approaches to the subclassification of muscarinic receptors, in: Recent Advances in Receptor Chemistry, eds. C. Melchiorre and M. Giannella (Elsevier Science Publishers B.V., Amsterdam) p. 195

Nelson, W.L., D.S. Freeman, P.D. Wilkinson and F.F. Vincenzi, 1973, Stereochemical analogs of a muscarinic, ganglionic stimulant. Cis- and trans-4-[N-(3-chlorophenyl)carbamoyloxy]-2-butenyltrimethylammonium iodides, J. Med. Chem. $16,506$.

Palacios, J.M., G. Bolliger, A. Closse, A. Enz, G. Gmelin and J. Malanowski, 1986, The pharmacological assessment of RS 86 (2-ethyl-8-methyl-2,8-diazaspiro-[4,5]-decan-1,3-dion hydrobromide). A potent, specific muscarinic acetylcholine receptor agonist, European J. Pharmacol. 125, 45.

Schwörer, H. and H. Kilbinger, 1988, Enhancement of guineapig intestinal peristalsis by blockade of muscarinic $\mathbf{M}_{\mathbf{1}}$-receptors, Br. J. Pharmacol. 93, 715.

Sneddon, P., D.P. Westfall, J. Colby and J.S. Fedan, 1984, A pharmacological investigation of the biphasic nature of the contractile response of rabbit and rat vas deferens to field stimulation, Life Sci. 35, 1903.
Tacke, R., H. Linoh, H. Zilch, J. Wess, U. Moser, E. Mutschler and G. Lambrecht, 1985, Synthesis and properties of the selective antimuscarinic agent cyclohexylphenyl(3-piperidinopropyl)silanol, Liebigs Ann. Chem. 2223.

Tacke, R., H. Linoh, K. Rafeiner, G. Lambrecht and E. Mutschler, 1988, Synthesis and properties of the selective antimuscarinic agent sila-hexocyclium methylsulfate, J. Organomet. Chem. (in press).

Watson, M., W.R. Roeske. P.C. Johnson and H.I. Yamamura 1984. [ ${ }^{3} \mathrm{H}$ ]Pirenzepine identifies putative $M_{1}$ muscarinic receptors in human stellate ganglia, Brain Res. 290, 179.

Waud, D.R. and R.B. Parker, 1971, Pharmacological estimation of drug-receptor dissociation constants. Statistical evaluation. II. Competitive antagonists. J. Pharmacol. Exp. Ther. 177, 13.

Wess, J., G. Lambrecht, U. Moser and E. Mutschler, 1984, A comparison of the antimuscarinic effects of pirenzepine and $\mathrm{N}$-methylatropine on ganglionic and vascular muscarinic receptors in the rat, Life Sci. 35, 553.

Williams, S.H. and A. Constanti, 1988, A quantitative study of the effects of some muscarinic antagonists on the guinea-pig olfactory cortex slice. Br. J. Pharmacol. 93, 855.

Zaugg, H.E., R.J. Michaels, H.J. Glenn, L.R. Swett, M. Freifelder, G.R. Stone and A.W. Weston, 1958, Tertiary carbinols of the piperazine series, I., J. Am. Chem. Soc. 80 , 2763. 